\title{
Adsorption and Desorption Behavior of Chlorotriazine Herbicides in the Agricultural Soils
}

Anil Kumar Singh and Swaranjit Singh Cameotra*

Institute of Microbial Technology, Sector 39 a, Chandigarh 160036, India

\begin{abstract}
The chlorotriazine herbicides have been applied worldwide for controlling of broadleaf weeds. These herbicides are known carcinogen and thus, their occurrence in surface and ground water is a cause of concern. In the present study, adsorption-desorption behavior of chlorotriazine herbicides namely simazine and atrazine was investigated. For the study, two different types of agricultural soil A (loam, 13.7\% organic matter content) and soil B (clay-loam, $4.8 \%$ organic matter content) was collected from Punjab, India. The adsorption-desorption study was carried out by batch equilibration procedure. The data fitted well into the Freundlich equation. The adsorption $K_{f}$ values indicated that the simazine has more soil adsorption ability than atrazine. The extent of herbicides adsorbed to the soil was more under low $\mathrm{pH}$ conditions and decreased with the increase in $\mathrm{pH}$ value. Increase in temperature decreased herbicides adsorption ability for both the soil types. The Gibb's free energy $(\Delta G)$ values were found less negative with the increase in temperature. Atrazine exhibited better desorption behavior than simazine. Soil A with high organic matter content exhibited sorption-desorption hysteresis. The results indicate that the soil organic matter content and aqueous solubility play an important role in the adsorption-desorption behavior of chlorotriazine herbicides. The present understanding of chlorotriazine herbicides sorption-desorption process will help to determine the herbicides fate and availability in soil, biodegradation, runoff and leaching.
\end{abstract}

Keywords: Simazine; Atrazine; Organic matter; Clay; Sorptiondesorption hysteresis

\section{Introduction}

The chlorotriazine herbicides namely atrazine and simazine have been widely used since 1950s for controlling of broadleaf weeds and annual grasses in agricultural and non-crop fields [1]. A very small fraction of applied herbicides reaches the target weeds, while the large fraction enters the environment, causing soil and water pollutions [2]. Consequently, the chlorotriazine herbicides have been detected in the surface and groundwater of the United States, Europe and Australia $[3,4]$.

United States Environmental Protection Agency (EPA) has reported atrazine and simazine as potential carcinogenic herbicides. Owing to their carcinogenic potentials, the presence of these herbicides in water is a cause of concern for public and regulatory agencies $[5,6]$. Atrazine and simazine has been reported to cause tumors and cancers, including breast, ovarian, and uterine, leukemia and lymphoma [1,7-9]. Atrazine is an endocrine disrupting chemical, interrupting regular hormone function, causing birth defects, reproductive tumors and weight loss particularly in amphibians as well as humans [7-9].

Literatures suggest that adsorption of herbicide to the soil is the key process that affects their ecotoxicological impact, environmental mobility and the rate of degradation $[10,11]$. The desorption process of herbicides is also important since it determines the release rate and the potential mobility of herbicides in the soil [10]. The adsorptiondesorption process of herbicide is influenced by several factors like organic matter content, soil texture, $\mathrm{pH}$, temperature, etc. [10-13]. The risk of herbicide entering the surface water and groundwater mainly comes from the adsorbed herbicide present in the soil. To protect surface and groundwater from pesticide contamination and evaluate their impact, extensive knowledge concerning degradation and sorption-desorption processes in the environment is required $[13,14]$.

The use of herbicides in India had gradually increased in recent years especially in the state of Punjab [15]. In 1999-2000 Punjab used nearly $923 \mathrm{~g} / \mathrm{ha}$ of pesticides which was highest among all the Indian states [15]. According to the Directorate of Plant Protection, Quarantine and Storage, Government of India, Punjab is among the top pesticide consuming state in India, thus having high risk of soil and water pollution. In Punjab chlorotriazine herbicides are mainly used for non-selective weed control on waste land and selective weed control in crops such as sorghum, maize, sugarcane, etc [11].

The aim of this work was to determine adsorption-desorption behavior of chlorotriazine herbicides namely atrazine and simazine in the typical agricultural soils of Punjab, India. Kinetics and isotherm adsorption experiments were carried out to have a better insight into the adsorption process. Factors affecting the adsorption efficiency of herbicides such as initial $\mathrm{pH}$ of the solution and temperature were also studied.

\section{Material and Methods}

\section{Chemical and physical characterization of agriculture soil}

The two representative soils used in the present study were collected from two different agricultural sites namely soil A (Rajpura; $30.48^{\circ} \mathrm{N}$, $76.6^{\circ} \mathrm{E}$ ) and soil B (Kharar; $30.74^{\circ} \mathrm{N}, 76.64^{\circ} \mathrm{E}$ ) from Punjab, India. The soils were collected from the surface layer $(0-20 \mathrm{~cm}$ depth), air-

*Corresponding author: Swaranjit Singh Cameotra, Institute of Microbial Technology, Sector 39 A, Chandigarh 160036, India, Tel: 0172-6665233; Fax 0172-2690632/585; E-mail: ssc@imtech.res.in

Received August 12, 2013; Accepted September 18, 2013; Published Septembe 25,2013

Citation: Anil Kumar S, Swaranjit Singh C (2013) Adsorption and Desorption Behavior of Chlorotriazine Herbicides in the Agricultural Soils. J Pet Environ Biotechnol 4: 154. doi:10.4172/2157-7463.1000154

Copyright: (c) 2013 Anil Kumar S, et al. This is an open-access article distributed under the terms of the Creative Commons Attribution License, which permits unrestricted use, distribution, and reproduction in any medium, provided the original author and source are credited. 
dried, and sieved to pass through $2.0 \mathrm{~mm}$ mesh. Chemical and physical characterization of agriculture soil was performed following previously described methods $[16,17]$.

\section{Chlorotriazine adsorption to the soil}

The atrazine and simazine herbicides adsorption isotherms of both the soils were performed using the batch equilibration procedure. To minimize changes in the ionic strength and avoid dispersion, $5 \mathrm{mM}$ $\mathrm{CaCl}_{2}$ solution was used as a background. First, herbicides were dissolved in methanol. Then the methanol solution was diluted by $5 \mathrm{mM} \mathrm{CaCl}$ solution to obtain the working solutions of different concentrations $(5,10,20,50$ and $100 \mathrm{mg} / \mathrm{l})$. The concentration of methanol in the working solution was kept constant at $0.1 \%$. Aliquots $(8 \mathrm{ml})$ of aqueous herbicide solution were added to $2 \mathrm{~g}$ of soil. Soil slurries were shaken on a horizontal shaker at $200 \mathrm{rpm}$ for a period of $24 \mathrm{~h}$ at $25 \pm 1^{\circ} \mathrm{C}$. Aliquots $(600 \mu l)$ were sampled from the supernatant at different time interval of $0,0.5,1,6,12$ and $24 \mathrm{~h}$. The samples were mixed with methanol $1: 1 \mathrm{v} / \mathrm{v}$, centrifuged (4000 rpm for $5 \mathrm{~min}$ ) for soil separation and then quantified by High-Performance Liquid Chromatography (HPLC). The amount of pesticide adsorbed was calculated as the average of the three replicates. A blank sample was also kept to assess the effects of chlorotriazine herbicide adsorption onto the tubes and the following possible degradation during the process.

\section{Chlorotriazine desorption from the soil}

Desorption experiments were performed instantly after the adsorption experiments. Supernatant was decanted and the herbicides residue present in the soil was analyzed. Then equal volume of the fresh $5 \mathrm{~mm} \mathrm{CaCl}$ solution was added. The mixtures were shaken on a horizontal shaker at $200 \mathrm{rpm}$ for $8 \mathrm{~h}$ at $25 \pm 1^{\circ} \mathrm{C}$. These steps were repeated three times consecutively.

\section{Chlorotriazine herbicides adsorption enthalpy}

Chlorotriazine herbicides adsorption enthalpy on both the soils was determined using the batch experiments as described above. The adsorption process was performed at two different temperatures $\left(25^{\circ} \mathrm{C}\right.$ and $35^{\circ} \mathrm{C}$ ). Herbicides concentrations used for the study were 5, 10, 20 and $50 \mathrm{mg} / \mathrm{l}$, respectively.

\section{Effect of $\mathrm{pH}$ on chlorotriazine herbicides adsorption}

The $\mathrm{pH}$ values of $5 \mathrm{mM} \mathrm{CaCl}$, solutions were adjusted to $5.0,7.0$ and 9.0 with the help of $5 \mathrm{~N} \mathrm{HCl}$ or $5 \mathrm{~N} \mathrm{NaOH}$. The chlorotriazine herbicides were then added to the solution so as to have concentrations of 5, 10, 20 and $50 \mathrm{mg} / \mathrm{l}$. Further, the experiment was performed in the same way as done for the kinetic study described above.

\section{Chlorotriazine quantification}

Chlorotriazine herbicides used in the present study were quantified using HPLC. Chromatographic analysis was performed with a Prominence HPLC system (Shimadzu, Japan) equipped with a UVVIS detector. The column was Phenomax- C18 $(5 \mu, 250 \mathrm{~mm} \times 4.6$ $\mathrm{mm})$ while mobile phase was methanol: water $(40 / 60, \mathrm{v} / \mathrm{v})$ at a flow rate of $0.5 \mathrm{mg} / \mathrm{ml}$. The samples were injected with constant injection volume of $20 \mu \mathrm{l}$ and detected at $254 \mathrm{~nm}$ absorbance wavelength. The chlorotriazine herbicides were identified and quantified by comparing the retention peaks of samples and authentic standard procured from Sigma-Aldrich, USA. External calibration curves with standard solutions between 1 and $50 \mathrm{mg} / 1$ were used for the calculations. The chemical structure of atrazine and simazine is shown in Figure 1.

\section{Data analysis}

Adsorption - desorption data were fitted on the Freundlich model: $\mathrm{S}=K_{f} \bullet \mathrm{C}^{1 / \mathrm{n}}$, where $\mathrm{S}$ is the amount of herbicides sorbed per mass of soil $(\mathrm{mg} / \mathrm{kg}$ soil), $\mathrm{C}$ is the concentration of the herbicide in the liquid phase $(\mathrm{mg} / \mathrm{l}), K_{f}$ is the Freundlich sorption coefficient $(1 / \mathrm{kg})$, and

$\mathrm{n}$ is a dimensionless parameter. Sorption coefficients $K_{f}$ and $\mathrm{n}$ were determined by plotting the logarithmic form of the Freundlich equation.

The adsorption coefficient $\left(K_{f}\right)$ was also calculated as a function of the Organic Carbon (OC) content and Organic Matter (OM) of the soil following equations $K_{\mathrm{OC}}=K_{f} / \% \mathrm{OC} \times 100$ and $K_{\mathrm{OM}}=K_{f} / \% \mathrm{OM}$ $\times 100$, respectively. The free energy change $(\Delta \mathrm{G}, \mathrm{cal} / \mathrm{mol})$ in the adsorption process was calculated by the following equation $\Delta \mathrm{G}=-\mathrm{RT}$ ln $K_{O M}$, where $\mathrm{R}$ is the gas constant $(2.0 \mathrm{cal} / \mathrm{K} / \mathrm{mol})$, and $\mathrm{T}$ is Kelvin temperature.

Hysteresis coefficient, $\mathrm{H}$, is calculated for the adsorptiondesorption isotherms according to the following equation $\mathrm{H}=(\mathrm{n}$ desorption)/ ( $\mathrm{n}$ adsorption), where $\mathrm{n}$ desorption and $\mathrm{n}$ adsorption are the Freundlich constants obtained for desorption and adsorption isotherms, respectively.

\section{Results and Discussion}

\section{Chemical and physical characterization of soil}

Table 1 shows chemical and physical features of agricultural soil samples used in the present study. Soil A showed higher organic matter content (13.7\%) than soil B (4.8\%). The chlorotriazine herbicides used in the present study were not detected in the soil samples, thus suggesting absence of atrazine and simazine pre-contamination.

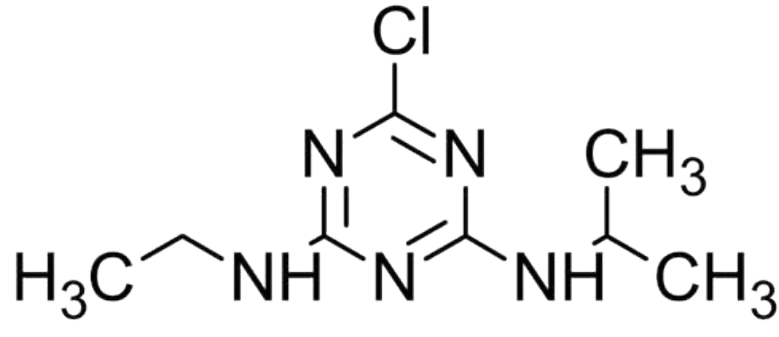

(a)

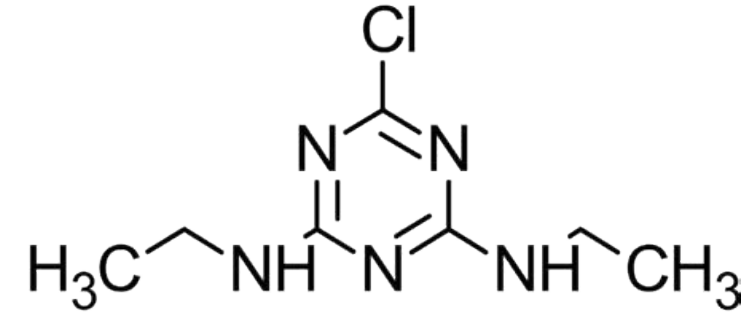

(b)

Figure 1: Chemical structure of (a) atrazine [1-Chloro-3-ethylamino-5-isopropylamino-2, 4, 6-triazine] and (b) simazine [6-chloro-N, N'-diethyl-1, 3, 5-triazine-2, 4-diamine]. The solubility of atrazine and simazine in water is $5 \mathrm{mg} / \mathrm{l}$ and $30 \mathrm{mg} / \mathrm{l}\left(\mathrm{pH} 7,25^{\circ} \mathrm{C}\right)$. 


\section{Chlorotriazine adsorption kinetics}

A preliminary adsorption experiment was performed to determine the contact time required for attaining adsorption equilibrium. As evident from Figure 2 the adsorption kinetics exhibited two distinct stages in both the soil types. The initial step was a very rapid adsorption followed by a slow adsorption. This observation is due to the fact that in initial stage a large number of vacant surface sites were available for adsorption, but once the vacant surfaces were occupied, the repulsive forces between the solute molecules of the solid and bulk phases came into play, thus delaying the adsorption process. Similar observation has been reported for few other organic herbicides $[18,19]$.

Herbicides adsorption equilibrium was reached within $5 \mathrm{~h}$ of incubation in both the soil types. The maximum chlorotriazine herbicides adsorption was observed in soil A. This may be due to high organic matter content in the soil [2]. As compared to atrazine, simazine exhibited better adsorption on both the soil. This may be attributed to the different water solubility of the herbicides [19]. Simazine with very low water solubility has greater tendency to get adsorbed to the soil.

\section{Chlorotriazine adsorption isotherms}

In the present study, no detectable amount of chlorotriazine degradation was found in the supernatant during the adsorption process. Thus, the reduction in the herbicide concentration in the solution was considered to be due to soil adsorption. The chlorotriazine herbicides exhibited non-linear sorption isotherms on soil A and B (Figure 3). Table 2 shows the adsorption parameters of chlorotriazine in soils A and B. The sorption of chlorotriazine herbicides in both the soil types fitted well within the Freundlich model. According to Calvet shape of the adsorption isotherm provides information regarding the adsorption mechanisms [19]. The value of the exponent $1 / n$ gives an indication of the favorability and the capacity of the adsorbentadsorbate system. Values $\mathrm{n}>1$ represent favorable adsorption conditions and $1<\mathrm{n}<10$ shows beneficial adsorption. The soils $A$ and $B$ showed non-liner isotherm $(n \neq 1)$, which indicated that chlorotriazine could adsorb to the clay fraction of soil as well as organic matter present in the soil. Similar adsorption isotherms have been previously reported for simazine [13,20] and atrazine adsorption [21,22]. Apart from soil organic matter, clays can also be an important sorbents for the adsorption of organic pesticides in the soil [23]. Simazine can sorb on hydrophobic microsites of smectites [24], and montmorillonite clay minerals [23]. Celis et al. [25] has reported that atrazine and simazine initially sorbed as neutral species on hydrophobic microsites of clay (montmorillonite).

\begin{tabular}{|c|c|c|c|c|c|c|c|c|}
\hline \multirow{2}{*}{ Soil } & \multirow{2}{*}{$\mathrm{pH}$} & Organic matter (\%) & Organic carbon (\%) & Conductivity $(\mu \mathrm{S} / \mathrm{cm})$ & Texture & \multicolumn{2}{|c|}{ Particles Size } \\
\cline { 7 - 9 } & & & & & Clay & Silt & Sand \\
\hline B & 6.4 & 13.7 & 8.6 & 186.2 & Loam & 25 & 35 \\
\hline
\end{tabular}

Table 1: Physical and chemicals properties of the agricultural soils collected from Punjab, India.
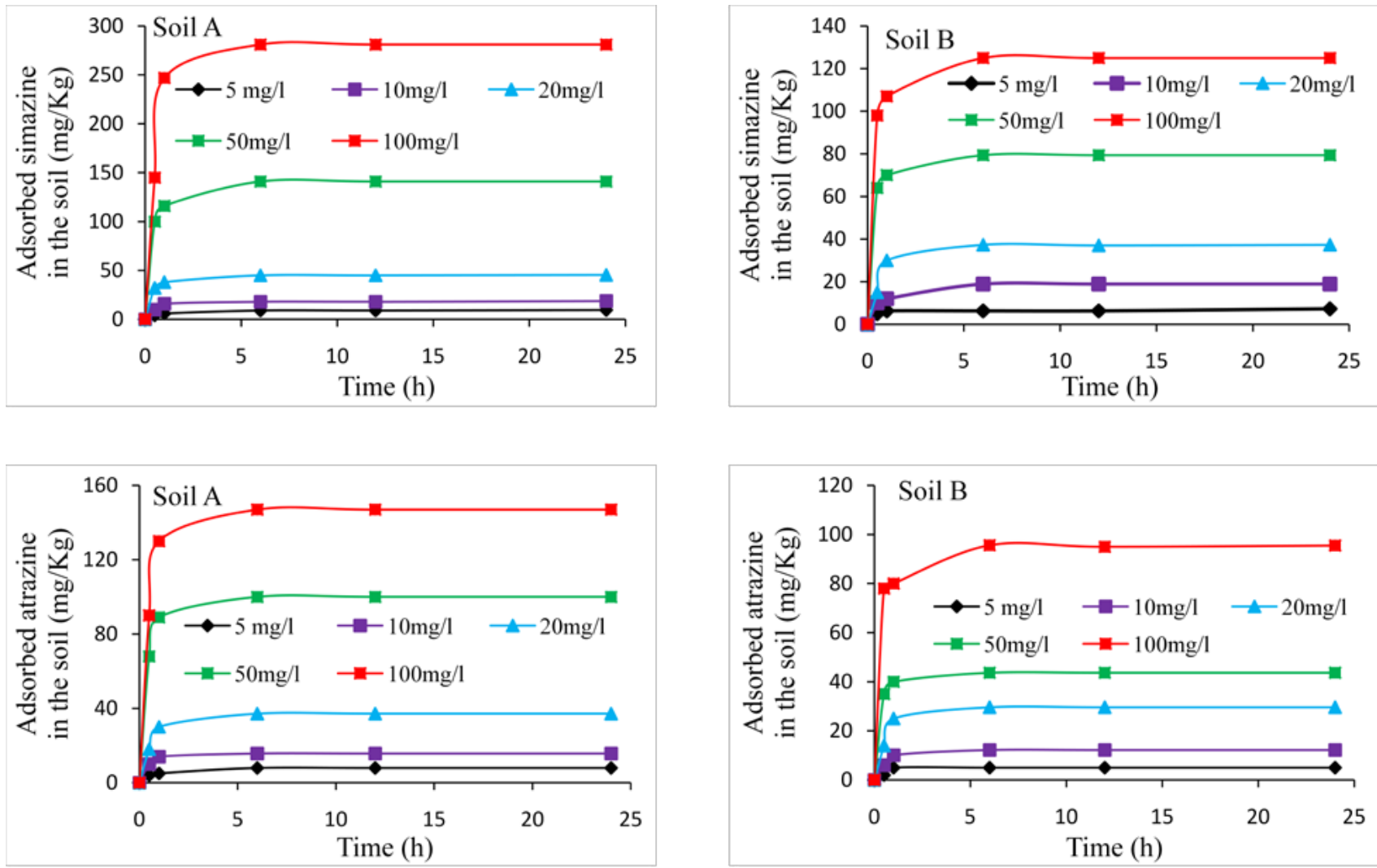

Figure 2: Adsorption kinetics of simazine and atrazine on agricultural soils A and B with different initial herbicide concentrations. The values represent an average value of three independent experiments. 

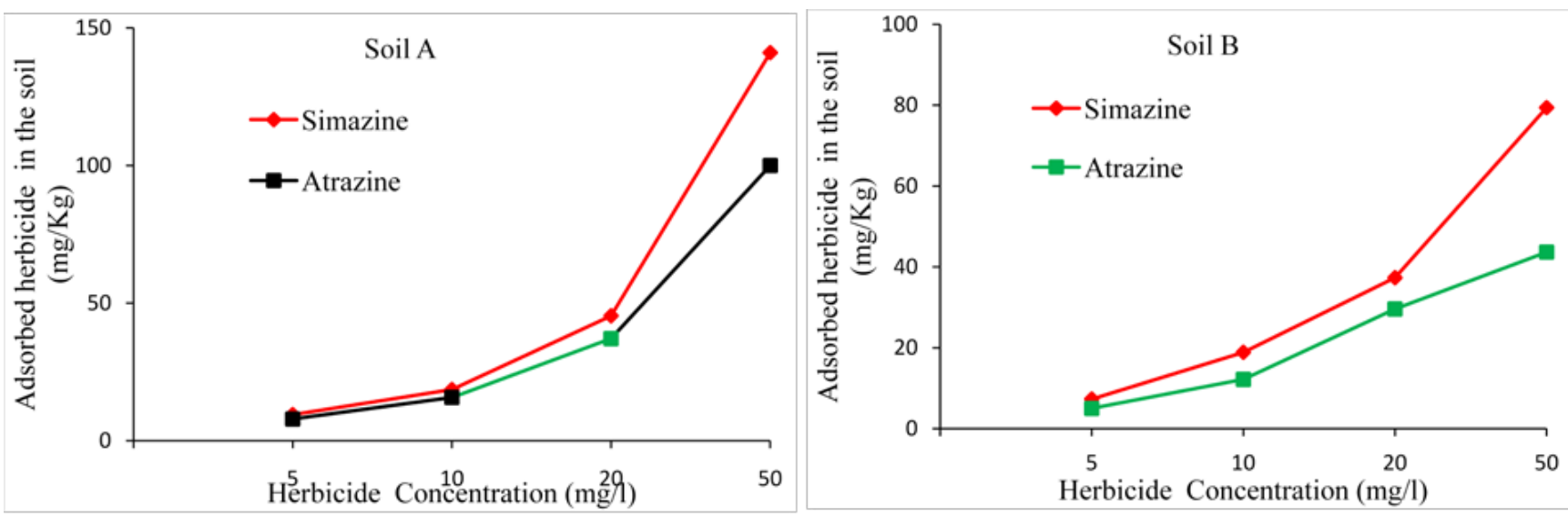

Figure 3: Adsorption isotherms of simazine and atrazine in soils A and B.

\begin{tabular}{|c|c|c|c|c|c|c|c|}
\hline Herbicides & Temperature (K) & Soil & $K f(\mathrm{mg} / \mathrm{Kg})$ & $1 / n$ & $\mathrm{R}^{2}$ & $K o c(\mathrm{mg} / \mathrm{kg})$ & $\mathrm{Kom}(\mathrm{mg} / \mathrm{kg})$ \\
\hline \multirow{4}{*}{ Simazine } & \multirow{2}{*}{298} & $A$ & 1.1581 & 0.1496 & 0.9978 & 13.4662 & 8.4532 \\
\hline & & $\mathrm{B}$ & 0.9138 & 0.3251 & 0.9868 & 43.5142 & 19.0357 \\
\hline & \multirow{2}{*}{308} & $A$ & 0.8559 & 0.3293 & 0.9933 & 17.8312 & 6.2474 \\
\hline & & $\mathrm{B}$ & 0.6039 & 0.4747 & 0.9925 & 28.7571 & 12.5812 \\
\hline \multirow{4}{*}{ Atrazine } & \multirow{2}{*}{298} & $A$ & 1.0113 & 0.2121 & 0.9889 & 11.7593 & 7.3817 \\
\hline & & B & 0.8395 & 0.2865 & 0.9811 & 39.9762 & 17.4896 \\
\hline & \multirow{2}{*}{308} & $A$ & 0.8009 & 0.3598 & 0.9846 & 9.3128 & 5.8459 \\
\hline & & B & 0.5898 & 0.3876 & 0.9942 & 28.0857 & 12.2875 \\
\hline
\end{tabular}

Table 2: The adsorption parameters of simazine and atrazine in agricultural soils at different temperature. The values represent an average value of three independent experiments.

Soil organic matter plays a crucial role in the adsorption of organic pesticides [2]. In the present study soil A with high organic matter content exhibited better herbicide sorption ability. In the soil A $47.5-70.5 \%$ and $40.0-50.0 \%$ of available simazine and atrazine was adsorbed, respectively. The soil $\mathrm{B}$, with less organic matter content exhibited $36.4-47.1 \%$ and $25.0-36.9 \%$ of adsorption for simazine and atrazine, respectively. The sorption of s-triazines on organic matter is governed by $\mathrm{H}$ bonds and proton transfer between s-triazines and acidic groups of humic substances [10]. The $K_{o c}$ values observed in the present study suggest that mineral constituents as well as soil organic matter contribute towards sorption of herbicides. Literatures suggest that the adsorption of chlorotriazine is more hysteretic for humic acid than for the clay [13]. Herbicide desorbs relatively easily from clay than from the organic matter, suggesting a stronger interaction between chlorotriazine and organic matter than between the chlorotriazine herbicides and clay. Thus, soil B that has more clay and less organic matter exhibited comparative low herbicide sorption.

\section{Chlorotriazine adsorption enthalpy}

Temperature play crucial role in determining the extent of herbicide that gets adsorbed on the soil. To determine chlorotriazine herbicides adsorption enthalpy in the agricultural soils, adsorption experiments were conducted at $25^{\circ} \mathrm{C}$ and $35^{\circ} \mathrm{C}$. Table 2 shows Freundlich constants at $25^{\circ} \mathrm{C}$ and $35^{\circ} \mathrm{C}$. At higher temperature, $K_{f}$ values declined for both the herbicides used in the present study. The values of the Freundlich exponent ' $n$ ' also decreased when the temperature increased from $298 \mathrm{~K}$ to $308 \mathrm{~K}$. In the soils $\mathrm{A}$ the $\Delta \mathrm{G}$ values for simazine changed from - 1272 $\mathrm{kJ} / \mathrm{mol}$ to $-1128 \mathrm{~kJ} / \mathrm{mol}$ when the temperature was increased from $298 \mathrm{~K}$ to $308 \mathrm{~K}$, thus indicating the feasibility and spontaneous nature of adsorption process at lower temperature. A similar observation was also made in soil B where $\Delta \mathrm{G}$ values increased from $-1756 \mathrm{~kJ} / \mathrm{mol}$ to $-1559 \mathrm{~kJ} / \mathrm{mol}$ with change in the temperature. In the soils $\mathrm{A}$ the $\Delta \mathrm{G}$ values for atrazine was found to change from $-1191 \mathrm{~kJ} / \mathrm{mol}$ to -1087 $\mathrm{kJ} / \mathrm{mol}$ when the temperature was increased from $298 \mathrm{~K}$ to $308 \mathrm{~K}$. A similar observation was also made in soil $\mathrm{B}$ where $\Delta \mathrm{G}$ values changed from $-1705 \mathrm{~kJ} / \mathrm{mol}$ to $-1545 \mathrm{~kJ} / \mathrm{mol}$. Decrease in $\Delta \mathrm{G}$ value suggest the feasibility and spontaneous nature of the adsorption process [13].

The chlorotriazine herbicides adsorption increased at lower temperature, indicating that the process is exothermic. The exothermic adsorption of chlorotriazine on soil may be explained by the fact that the adsorbate-adsorbent bonds were weakened with increasing temperature. Temperature induced change in aqueous solubility of herbicides may also influence the adsorption process [26]. Higher temperatures increase herbicides solubility and lower the tendency to get sorbed on the soils. During summer in Punjab temperature generally remain higher than $25^{\circ} \mathrm{C}$. Thus, the probability of surface and ground water contamination with chlorotriazine herbicides is more during summer rains than in the winter. Chlorotriazine herbicides applied during winter (when temperature remains below $25^{\circ} \mathrm{C}$ ) have more tendency to remain adhered to the soil.

\section{Effect of $\mathrm{pH}$ on chlorotriazine adsorption}

The adsorption capacity of herbicides is significantly influenced by the initial $\mathrm{pH}$ of the solution. In the present study adsorption of chlorotriazine herbicides in the soils were more at low $\mathrm{pH}$ and decreased with the increase in $\mathrm{pH}$ of the solution (Table 3). Thus, indicating that the availability of the adsorption sites to chlorotriazine molecules reduced as the $\mathrm{pH}$ value increased. This observation is in accordance with the general trend observed for many other pesticides $[13,27,28]$. The number of protonated surface on the adsorbent increases with 
decreasing $\mathrm{pH}$ and thus the coulombic attractive forces between more positively charged surfaces and herbicide increases at lower $\mathrm{pH}$ values [13]. In soil A, the $K_{f}$ value for simazine was $1.6235 \mathrm{mg} / \mathrm{kg}$ at $\mathrm{pH} 5$, which is 3.2 times higher than those of corresponding value at $\mathrm{pH} 9$. For soils B the $K_{f}$ value for simazine at $\mathrm{pH} 5$ was $1.1610 \mathrm{mg} / \mathrm{kg}$ which is 2.3 times higher than the corresponding value at $\mathrm{pH} 9$. Similarly in soil A, the $K_{f}$ value for atrazine was $1.4938 \mathrm{mg} / \mathrm{kg}$ at $\mathrm{pH}$, which was 2.7 times higher than those of corresponding value at $\mathrm{pH}$ 9. In soils $\mathrm{B}$, the $K_{f}$ value at $\mathrm{pH} 5$ and $\mathrm{pH} 9$ changed by $\sim 1.5$ times only. The differences may be due to the different concentration of organic matter. Soil A with high organic matter content has a better buffer capacity for $\mathrm{pH}$ change [13]. Organic matter present in the soil is known to act as a $\mathrm{pH}$ buffering agent in nature [29].

\section{Desorption behavior of chlorotriazine on soils}

Looking into the desorption process of herbicides is vital since it determines the release rate and the potential mobility of herbicides in the soil as well as the treatment strategy for the contaminated soils. The herbicides with a lower desorption rate may possess higher risk to the successive crops. Thus, desorption kinetic studies were conducted to assess the desorption potential of adsorbed chlorotriazine herbicides and the results are shown in Table 4 . The rate of desorption was comparatively fast in soil B as compared to the soil A. The organic matter content may play an important role in the desorption process [13]. Soil B with little organic matter content exhibited the highest desorption $K_{f}$ for both the herbicides (Table 4 ). The $K_{f}$ values of the desorption process suggested that atrazine has better desorption ability as compared to simazine. This observation may be attributed to the different solubility of atrazine and simazine. Atrazine with a comparatively better water solubility has higher tendency to enter the aqueous phase and get desorbed from the soil.

\section{Hysteresis in adsorption and desorption}

Occurrence of hysteresis in adsorption-desorption reaction in the soils suggests that adsorption of pesticides occurs with a limited degree of reversibility depending upon both the physico-chemical properties of the molecules and the soils involved in the process $[13,30]$. Generally, a value of hysteresis index close to 1 means that desorption and sorption has similar rate, therefore, hysteresis is absent. On the other hand, a value of hysteresis index less than 1 indicates that the rate of desorption is lower than that of sorption, thus hysteresis takes place [31]. In the soil A, the hysteresis index was less than 1 for both the herbicides (Table 4). However, in the soil B the hysteresis index for simazine and atrazine was less than 1 and nearly equal to 1 , respectively. The soil B with low organic matter content and atrazine with a higher water solubility supported desorption process in the present study. Results suggest that organic matter and aqueous solubility of herbicides significantly influence the adsorption-desorption hysteresis. The entrapping of herbicide molecules within the condensed soil organic matter makes a significant contribution to adsorption-desorption hysteresis. In soils with high organic matter content, the adsorption-desorption hysteresis is mainly controlled by organic matter. However, involvement of the soil mineral composition in desorption behavior of herbicides cannot be ignored [14]. The hysteresis index values observed in the present study, suggest that the adverse effect of simazine and atrazine on the succession crop should be noticed, especially when chlorotriazine were applied on soils with high organic matter content, for example, soil A. While applying atrazine to soil with low organic matter content like soil B, attention should be paid to the risk of groundwater and surface water contamination from the herbicide.

\section{Conclusions}

This study contributes to the understanding of simazine and atrazine sorption-desorption process in the two types of agricultural soil of Panjab, India. Organic matter content of soil has significant influence on the adsorption of simazine and atrazine. Soil with high organic matter content has better herbicide's adsorption ability. Soils of Punjab with higher organic matter content exhibited enhanced simazine and atrazine sorption capacity. The increase in temperature and $\mathrm{pH}$ of the solution had a negative effect on the adsorption process. Organic matter content also contributed significantly towards simazine and atrazine desorption process. The results from the present study would help in designing of effective herbicide management strategies in Punjab, India. This also highlights the feasibility of adverse effect of soil adsorbed chlorotriazine on the succession crops.

\begin{tabular}{|c|c|c|c|c|c|c|c|}
\hline Herbicides & $\mathrm{pH}$ & Soil & $K f(\mathrm{mg} / \mathrm{Kg})$ & $1 / n$ & $\mathrm{R}^{2}$ & $K O C(\mathrm{mg} / \mathrm{kg})$ & $\mathrm{Kom}(\mathrm{mg} / \mathrm{kg})$ \\
\hline \multirow{6}{*}{ Simazine } & \multirow{2}{*}{5} & A & 1.6235 & 0.0376 & 0.9928 & 18.8779 & 11.8503 \\
\hline & & B & 1.1610 & 0.2881 & 0.9926 & 55.2857 & 24.1875 \\
\hline & \multirow{2}{*}{7} & A & 1.1581 & 0.1496 & 0.9978 & 13.4662 & 8.4532 \\
\hline & & B & 0.9138 & 0.3251 & 0.9868 & 43.5142 & 19.0357 \\
\hline & \multirow{2}{*}{9} & $A$ & 0.5071 & 0.2296 & 0.9894 & 5.8965 & 3.7014 \\
\hline & & B & 0.4994 & 0.3865 & 0.9874 & 23.7809 & 10.4041 \\
\hline \multirow{6}{*}{ Atrazine } & \multirow{2}{*}{5} & A & 1.4938 & 0.0024 & 0.9794 & 17.3697 & 10.9036 \\
\hline & & B & 1.0956 & 0.2132 & 0.9878 & 52.1714 & 22.825 \\
\hline & \multirow{2}{*}{7} & A & 1.0113 & 0.2121 & 0.9889 & 11.7593 & 7.3817 \\
\hline & & B & 0.8395 & 0.2865 & 0.9811 & 39.9762 & 17.4896 \\
\hline & \multirow{2}{*}{9} & $A$ & 0.5459 & 0.3301 & 0.9744 & 6.3476 & 3.9846 \\
\hline & & $B$ & 0.6968 & 0.3231 & 0.9719 & 33.1809 & 14.5166 \\
\hline
\end{tabular}

Table 3: The adsorption parameters of simazine and atrazine in agricultural soils at different $\mathrm{pH}$. The values represent an average value of three independent experiments.

\begin{tabular}{|c|c|c|c|c|c|c|c|}
\hline Herbicides & Soil & $K f(\mathrm{mg} / \mathrm{Kg})$ & $1 / n$ & $\mathrm{R}^{2}$ & $K o c(\mathrm{mg} / \mathrm{kg})$ & Kom (mg/kg ) & Hysteresis index \\
\hline \multirow{2}{*}{ Simazine } & A & 0.5717 & 0.4738 & 0.9957 & 6.6476 & 4.1729 & 0.315 \\
\hline & B & 0.4979 & 0.4940 & 0.9814 & 23.7095 & 10.3729 & 0.658 \\
\hline \multirow{2}{*}{ Atrazine } & A & 0.5238 & 0.4043 & 0.9936 & 6.090 & 3.8233 & 0.525 \\
\hline & B & 0.6780 & 0.3015 & 0.9774 & 32.285 & 14.125 & 0.950 \\
\hline
\end{tabular}

Table 4: The desorption parameters of simazine and atrazine in the soils. 
Citation: Anil Kumar S, Swaranjit Singh C (2013) Adsorption and Desorption Behavior of Chlorotriazine Herbicides in the Agricultural Soils. J Pet Environ Biotechnol 4: 154. doi:10.4172/2157-7463.1000154

\section{Acknowledgements}

Anil K Singh thanks the UGC, Govt. of India for his research fellowship. The authors thank the Director, IMTECH for providing the facilities for this work.

\section{References}

1. Kettles MK, Browning SR, Prince TS, Horstman SW (1997) Triazine herbicide exposure and breast cancer incidence: an ecologic study of Kentucky counties. Environ Health Perspect 105: 1222-1227.

2. Arias-Estévez M, López-Periago E, Martínez-Carballo E, Simal-Gándara J, Mejuto JC, et al. (2008) The mobility and degradation of pesticides in soils and the pollution of groundwater resources. Agr Ecosyst Environ 123: 247-260.

3. Cox L, Celis R, Hermosín MC, Cornejo J (2000) Natural soil colloids To retard simazine and 2,4-D leaching in soil. J Agric Food Chem 48: 93-99.

4. Cox C (1992) A New List of Carcinogenic Pesticides Used on Food. Journal of Pesticide Reform.

5. Eldridge JC, Tennant MK, Wetzel LT, Breckenridge CB, Stevens JT (1994) Factors affecting mammary tumor incidence in chlorotriazine-treated female rats: hormonal properties, dosage, and animal strain. Environ Health Perspect 11: 29-36.

6. Wetzel LT, Luempert LG 3rd, Breckenridge CB, Tisdel MO, Stevens JT, et al. (1994) Chronic effects of atrazine on estrus and mammary tumor formation in female Sprague-Dawley and Fischer 344 rats. J Toxicol Environ Health 43 : 169-182.

7. Fan W, Yanase T, Morinaga H, Gondo S, Okabe T, et al. (2007) Atrazineinduced aromatase expression is SF-1 dependent: implications for endocrine disruption in wildlife and reproductive cancers in humans. Environ Health Perspect 115: 720-727.

8. Hayes TB, Khoury V, Narayan A, Nazir M, Park A, et al. (2010) Atrazine induces complete feminization and chemical castration in male African clawed frogs (Xenopus laevis). P Natl Acad Sci USA 107: 4612-4617.

9. Weber GJ, Sepúlveda MS, Peterson SM, Lewis SS, Freeman JL (2013) Transcriptome alterations following developmental atrazine exposure in zebrafish are associated with disruption of neuroendocrine and reproductive system function, cell cycle, and carcinogenesis. Toxicol Sci 132: 458-466.

10. Liu Y, Xu Z, Wu X, Gui W, Zhu G (2010) Adsorption and desorption behavio of herbicide diuron on various Chinese cultivated soils. J Hazard Mater 178 . 462-468.

11. Singh $P$, Suri CR, Cameotra SS (2004) Isolation of a member of Acinetobacter species involved in atrazine degradation. Biochem Biophys Res Commun 317 $697-702$

12. Siripattanakul S, Wirojanagud W, McEvoy J, Limpiyakorn T, Khan E (2009) Atrazine degradation by stable mixed cultures enriched from agricultural soil and their characterization. J Appl Microbiol 106: 986-992.

13. Flores C, Morgante V, González M, Navia R, Seeger M (2009) Adsorption studies of the herbicide simazine in agricultural soils of the Aconcagua valley, central Chile. Chemosphere 74: 1544-1549.

14. Wu C, Zhang S, Nie G, Zhang Z, Wang J (2011) Adsorption and desorption of herbicide monosulfuron-ester in Chinese soils. J Environ Sci (China) 23 : 1524-1532.
15. Gill MS (2003) Punjab society : perspectives and challenges. Concept Pub. Co New Delhi India.

16. Singh AK, Cameotra SS (2013) Efficiency of lipopeptide biosurfactants in removal of petroleum hydrocarbons and heavy metals from contaminated soil. Environ Sci Pollut Res Int.

17. Nelson DW, Sommers LE (1996) Total carbon, organic carbon, and organic matter. In: Methods of Soil Analysis, Part 3, $4^{\text {th }}$ edn Bigham, JM. ASA and SSSA, Madison, WI, 961-1010.

18. Rama Krishna K, Philip L (2008) Adsorption and desorption characteristics of lindane, carbofuran and methyl parathion on various Indian soils. J Hazard Mater 160: 559-567.

19. Calvet R (1989) Adsorption of organic chemicals in soils. Environ Health Perspect 83: 145-177.

20. Albarrán A, Celis R, Hermosín MC, López-Piñeiro A, Cornejo J (2004) Behaviour of simazine in soil amended with the final residue of the olive-oil extraction process. Chemosphere 54: 717-724.

21. Dehghani M, Nasseri S, Amin S, Nadafi K, Taghavi M, et al. (2005) Atrazine adsorption-desorption behavior in Darehasaluie Kavar corn field soil in Fars Province of Iran. Iran J Environ Health Sci Eng 2: 221-228.

22. Krutz LJ, Senseman SA, Mclnnes KJ, Zuberer DA, Tierney DP (2003) Adsorption and desorption of atrazine, desethylatrazine, deisopropylatrazine, and hydroxyatrazine in vegetated filter strip and cultivated soil. J Agric Food Chem 51: 7379-7384.

23. Rafael CG, Juan C, Hermosin Gavino MC, Koskinen WC (1997) Sorptiondesorption of atrazine and simazine by model soil colloidal components. Soil Sci Soc Am J 61: 436-443.

24. Lucía CM, Rafael CG, Hermosin Gavino MC, Juan C, Zsolnay A, et al. (2000) Effect of organic amendments on herbicide sorption as related to the nature of the dissolved organic matter. Environ Sci Technol 34: 4600-4605.

25. Celis R, Cornejo J, Hermosín MC, Koskinen WC (1998) Sorption of atrazine and simazine by model associations of soil colloids. Soil Sci Soc Am J 62 165-171.

26. Gunasekara AS, Troiano J, Goh KS, Tjeerdema RS (2007) Chemistry and fate of simazine. Rev Environ Contam Toxicol 189: 1-23.

27. Boivin A, Cherrier R, Schiavon M (2005) A comparison of five pesticides adsorption and desorption processes in thirteen contrasting field soils. Chemosphere 61: 668-676.

28. Ertli T, Marton A, Földényi R (2004) Effect of $\mathrm{pH}$ and the role of organic matter in the adsorption of isoproturon on soils. Chemosphere 57: 771-779.

29. Helling CS, Chesters G, Corey RB (1964) Contribution of Organic Matter and Clay to Soil Cation-Exchange Capacity as Affected by the $\mathrm{pH}$ of the Saturating Solution. Soil Sci Soc Am J 28: 517-520.

30. Kovaios ID, Paraskeva CA, Koutsoukos PG, Payatakes ACh (2006) Adsorption of atrazine on soils: model study. J Colloid Interface Sci 299: 88-94.

31. Tang Z, Zhang W, Chen Y (2009) Adsorption and desorption characteristics of monosulfuron in Chinese soils. J Hazard Mater 166: 1351-1356. 